\title{
First fossil tumbling flower beetle-type larva from 99 million-year-old amber
}

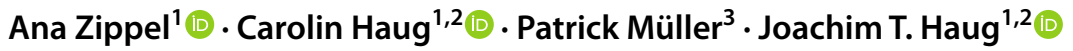

Received: 8 November 2021 / Accepted: 30 December 2021 / Published online: 3 March 2022

(c) The Author(s) 2022

\begin{abstract}
Beetle larvae often differ significantly in morphology from their adult counterparts. Therefore, it should be surprising that these immatures are often not considered to the same extent as the adult beetles. As an example, the fossil record of most beetle groups is largely represented by adult specimens. Representatives of Mordellidae, the group of tumbling flower beetles, have a cosmopolitan distribution with myriads of formally described species, based mostly on adult male specimens. Mordellidae is also well represented in the fossil record, but again only by adults; not a single fossil specimen of a larva has been reported until now. We report a new well-preserved beetle larva in 99 million-year-old Kachin amber. The larva possesses specialisations not known from the modern larvae of Mordellidae, but otherwise is clearly similar to them in many aspects. It appears possible that the fossil represents yet another holometabolan larva in Kachin amber that is associated with life within wood and/or fungi, and therefore, may have contributed to carbon cycling of the past.
\end{abstract}

Keywords Cretaceous $\cdot$ Burmese amber $\cdot$ Kachin amber $\cdot$ Mordellidae $\cdot$ Fossil larva

\section{Introduction}

Beetles come in various forms and sizes and fulfil myriads of important ecosystem functions, both as adults, as well as in their larval forms. Mordellidae, the group of tumbling flower beetles, includes about 1500 formally described species in the modern fauna (Jackman and Lu 2002; Lawrence and Ślipinśki 2010). Tumbling flower beetles have a cosmopolitan distribution (Lawrence and Ślipinśki 2010), with highest species richness in the tropical zone, followed by relatively high numbers in subtropical and warm temperate zones (Bao et al. 2019a). Adult tumbling flower beetles are often found on flowers and represent one of the most species-rich groups among beetle pollinators of flowering plants (Magnoliopsida, "angiosperms") (Bao et al. 2019b). This close

Communicated by Handling Editor: Mike Reich.

Ana Zippel

ana.zippel@palaeo-evo-devo.info

1 Ludwig-Maximilians-Universität München, Biocenter, Großhaderner Str. 2, 82152 Planegg-Martinsried, Germany

2 GeoBio-Center at LMU, Richard-Wagner-Str. 10, 80333 Munich, Germany

3 Kreuzbergstr. 90, 66482 Zweibrücken, Germany connection to flowering plants also explains why this group is named tumbling flower beetles. The other part of the name is explained by the specific movement of the abdomen that brings them into the take-off position, so called "tumbling". In contrast to the adults, the larvae are mostly hidden inside herbaceous plant organs or wood where they feed directly on plant material or on associated fungi material (Lawrence 1991a; Lawrence and Ślipinśki 2010).

Adult tumbling flower beetles can often be encountered in the field and have, therefore, been investigated regularly; the larvae seem often omitted from research, possibly due to their often hidden way of life. According to Zemoglyadchuk and Buialskaya (2016), for fewer than 50 species of Mordellidae, the morphology of their larvae has been described. Even though the larvae of extant species that affect crops while feeding have a substantial effect on humans directly, including larvae of Mordellidae, they are not as well represented in studies as one would expect (Liu et al. 2018). The ratio of described larvae per number of known species is quite low compared to other groups of beetles and their relatives (see discussion in Haug et al. 2021a). Due to the scarceness of data on larvae, the ecology of most tumbling flower beetle larvae remains unknown as well (Liu et al. 2018). 
Mordellidae is not a "new" group. The oldest fossil representatives are known already from the Jurassic period: Praemordella martynovi (Ščegoleva-Barovskaya, 1929) and Liaoximordella hongi (Wang, 1993). In general, the fossil record of Mordellidae seems to be quite good (Peris and Rust 2020) with approximately 50 specimens known so far and 38 different species formally described, either clearly of the group or possibly closely related to it. At least ten of these were found in amber of various types (New Jersey, Canadian, Burmese, Spanish, Fushun, Baltic, Dominican and Mexican amber) (Peris and Ruzzier 2013; Bao et al. $2019 \mathrm{c})$. It has been suggested that understanding the early evolution of Mordellidae is important for understanding the larger group of Tenebrionoidea and ultimately Coleoptera as a whole (McKenna and Farrell 2009; Bao et al. 2019c). The fossils of this group are not only contributing to the understanding of evolution of the group, but also their interrelationships with plants in the ecosystems of past times. Both beetles and flowering plants were common by the middle of the Cretaceous and the great radiation of flowering plants apparently benefitted from pollinators (Bao et al. 2019b). It seems well accepted that the group of Mordellidae, with their adults, represented one of the pollinator groups of the Cretaceous (Bao et al. 2019b) and co-evolved with flowering plants (Bao et al. 2018). Larvae will have had a quite a different ecology and are expected to reveal different ecosystem functions.

Here, we present a very well-preserved fossil beetle larva specimen preserved in Kachin amber from the Cretaceous of Myanmar. This specimen is interpreted as a possible larva of the group Mordellidae based on the similarity to extant specimens of the group. We discuss implications of this new find.

\section{Materials and methods}

\section{Materials}

In the centre of this study is a single fossil specimen, BUB 3195. The specimen originates from 99 million-year-old Cretaceous Myanmar Kachin amber and comes from the collection of one of the authors (PM). The specimen was legally acquired on June 22, 2016. It is preserved in Cretaceous Kachin amber (c. 99 million-years-old) from the Hukawng Valley, Myanmar (Cruickshank and Ko 2003; Shi et al. 2012; Yu et al. 2019).

For comparison, an extant larva of the group Mordellidae was documented as well. It is part of the collection of the Centrum für Naturkunde (CeNak), Leibniz-Institut zur Analyse des Biodiversitätswandels (LIB), Hamburg. The specimen has the repository number ZMH 8530.

\section{Documentation methods}

The fossil specimen was documented on a Keyence VHX-6000 digital microscope in front of white and black background under different illumination settings (crosspolarised co-axial light and low-angle ring light) (Haug et al. 2013a, 2018). All images were recorded as composite images (Haug et al. 2011), combining several images of varying focus and several adjacent image details as well as different exposure times (HDR, cf. Haug et al. 2013b).

The extant specimen for comparison was photographed in its original storage liquid (70\% ethanol) with a supermacro setup. A Canon EOS 650D equipped with a MP-E $65 \mathrm{~mm}$ was used. Lighting was provided by two flashes equipped with polariser filters. A perpendicularly oriented filter was put in front of the lens, providing cross-polarised light. Images were recorded as compound images (Haug et al. 2011).

Images of both, extant and fossil, specimens were further processed and colour-marked with Adobe Photoshop CS2.

\section{Results}

Here, we present two specimens of larvae: an extant specimen of a tumbling beetle larva and a fossil specimen. A general description of larvae of Mordellidae, shared also by both newly described specimens, is provided as a background. Special emphasis was lain on a particular characteristic, a process (whether paired or single) on the terminal end, present in extant larvae of Mordellidae and the fossil.

\section{General description of tumbling beetle larvae}

Elongate, roughly cylindrical body. Body differentiated into an anterior region composed of head and a posterior region composed of trunk. Trunk differentiated into an anterior region (thorax) and a posterior region (abdomen) (Figs. 1, 2). Head hypognathous (mouth parts facing downwards). Antennae discernible, number of elements can vary between species. Thorax with three segments (pro-, meso- and metathorax). Thorax with pair of locomotory appendages (legs) on each segment (absent in some extant species of Mordellistena). Elements of legs vary between species. Abdomen with ten discernible units. Terminal end of abdomen with a paired or a single process. Trunk appears overall rather soft, no prominent sclerites, cuticle with distinct folds between segments. 


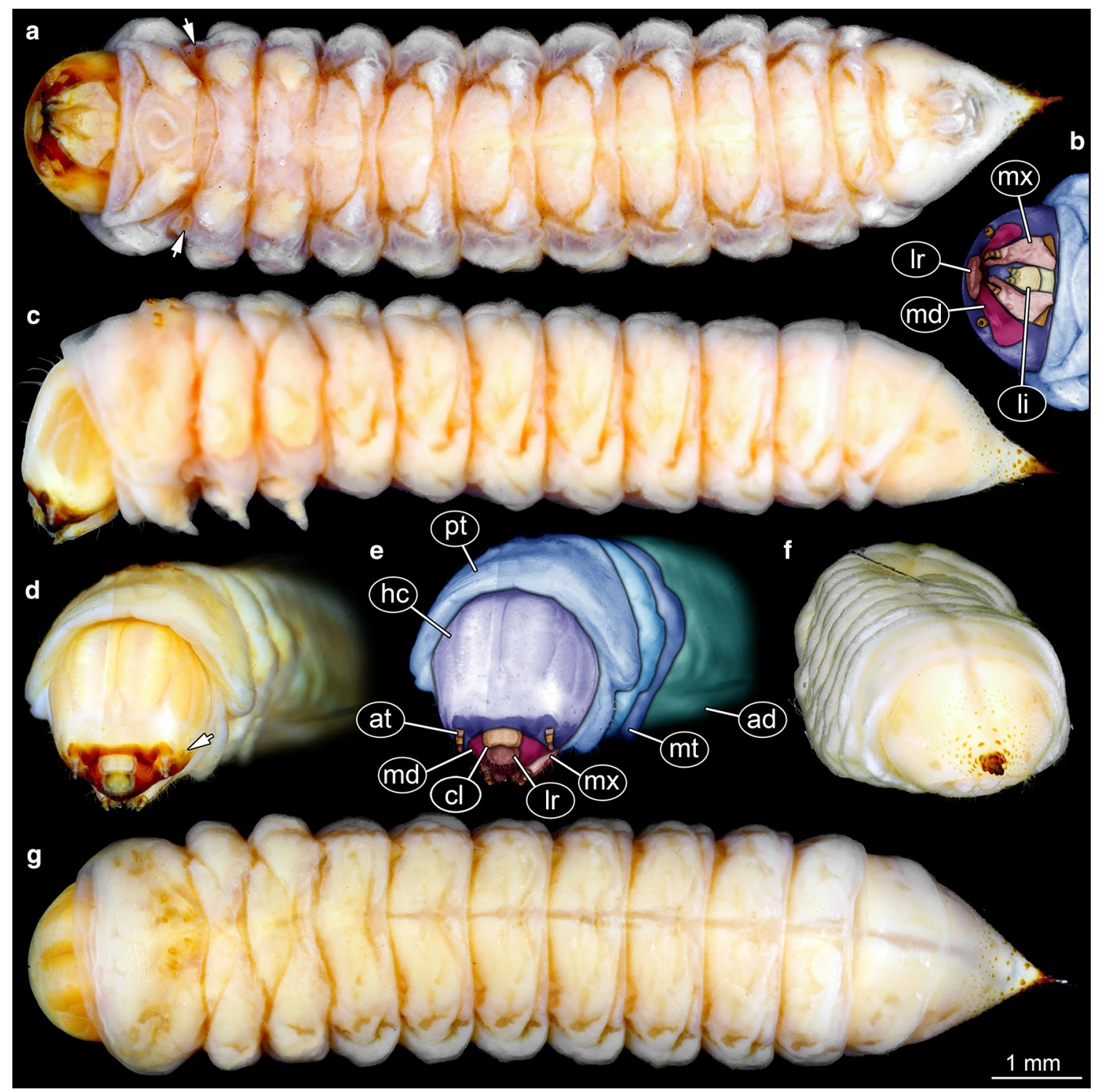

Fig. 1 Extant specimen ZMH 8530, tumbling flower beetle larva: a habitus in ventral view, tracheal spiracles on mesothorax discernible (white arrows); $\mathbf{b}$ colour-marked version of head, based on $\mathbf{a} ; \mathbf{c}$ habitus in lateral view; $\mathbf{d}$ habitus in anterior view, possible stemmata

\section{Extant specimen ZMH 8530}

Total body length approximately $12.4 \mathrm{~mm}$. Head roughly globular, slightly longer than wide, $1.1 \times(\sim 2 \mathrm{~mm}$ long $)$. Possible stemmata discernible antero-laterally (Fig. 1d). Antenna (appendage of post-ocular segment 1) with three elements discernible (Fig. 1d, e), $0.13 \times$ the length of the head $(\sim 0.25 \mathrm{~mm})$. All elements approximately of same length.

Labrum (derivative of ocular segment) wider than long, $1.6 \times(\sim 0.23 \mathrm{~mm}$ long$)$, oval in frontal view, posterior edge discernible (white arrow); e colour-marked version of $\mathbf{d} ; \mathbf{f}$ habitus in posterior view; $\mathbf{g}$ habitus in dorsal view. ad abdomen, at antenna, $c l$ clypeus, $h c$ head capsule, $l i$ labium, $l r$ labrum, $m d$ mandible, $m t$ metathorax, $m x$ maxilla, $p t$ prothorax

connected to prominent clypeus (Fig. 1e), anterior edge bears seven discernible micro-setae.

Mandibles (paired appendages of post-ocular segment 3) symmetrical, strongly sclerotized, with no setae discernible. Maxillae (paired appendages of post-ocular segment 4) longer than wide, trapezoid in ventral view. Each maxilla with several parts: latero-proximally small element discernible (cardo), triangular in ventral view; anteroposteriorly larger element discernible (stipes), longer than wide, pentagonal in functional ventral view (posterior view); distally palp ( $\sim 0.2 \mathrm{~mm}$ long) with three elements 


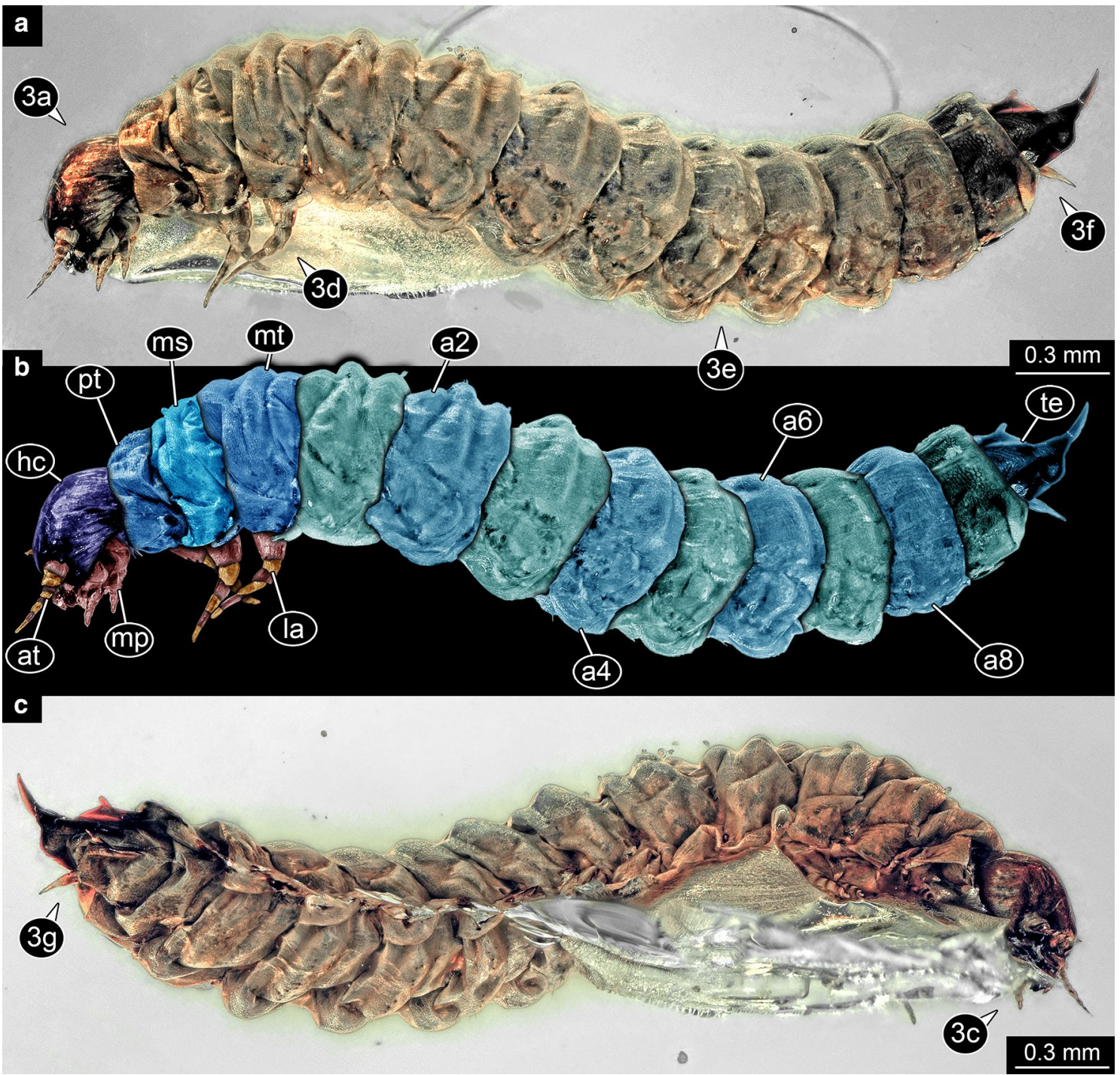

Fig. 2 Fossil specimen BUB 3195, tumbling flower beetle larva: a habitus in latero-dorsal view; b colour-marked version of $\mathbf{a} ; \mathbf{c}$ habitus in latero-ventral view (black circles indicate close-ups of habitus

discernible (Fig. 1b). Maxillae bear setae (Fig. 1d, e), no spines discernible.

Labium (conjoined appendages of post-ocular segment 5) of rectangular shape in ventral view, with transverse suture dividing it into proximal and distal part (Fig. 1b). Distal part with pair of palps, each palp with two elements (Fig. 1b).

Prothorax oval from dorsal view (Fig. 1g), also largest segment of trunk, wider than long, $2 \times(\sim 1.37 \mathrm{~mm}$ long $)$. Meso- and metathorax subsimilar, with dorsal body surface subdivided by multiple folds. Mesothorax wider than long, $4.2 \times(\sim 0.4 \mathrm{~mm}$ long$)$, median part slightly shorter than lateral. Mesothorax postero-laterally with a pair of oval tracheal spiracles in ventral view (Fig. 1a). Metathorax wider than long, $3.5 \times(\sim 0.8 \mathrm{~mm}$ long $)$, longer than median part of mesothorax, $1.9 \times$. available in Fig. 3). $a 2-a 8$ abdomen segments $2-8$, at antenna, $h c$ head capsule, la locomotory appendages, $m p$ maxillary palp, $m s$ mesothorax, $m t$ metathorax, $p t$ prothorax, te terminal end

Legs relatively short and stout, each with three discernable elements (Fig. 1a, c).

Abdomen segments 1-7 subsimilar $(\sim 0.8 \mathrm{~mm}$ long, $2.8 \mathrm{~mm}$ wide). Segment 8 almost pentagonal in dorsal view, longest part shorter than wide, $4.3 \times(0.5 \mathrm{~mm}$ long), longer than segments $1-7$, shorter than prothorax, $2.7 \times$. Trunk end (possible compound of several segments) triangular in dorsal view, terminal end with sclerotized spine-like process (with process $\sim 2 \mathrm{~mm}$ long, anteriorly $\sim 1.9 \mathrm{~mm}$ wide). Posterior part of trunk end with small sclerotized tubercles and setae (Fig. 1a, c, f, g). In dorsal view, more than 20 tubercles discernible, descending in number and enlarging in size postero-dorsally (Fig. 1g). In ventral view, tubercles discernible only on the posterior part of the trunk end and proximal part of the process 


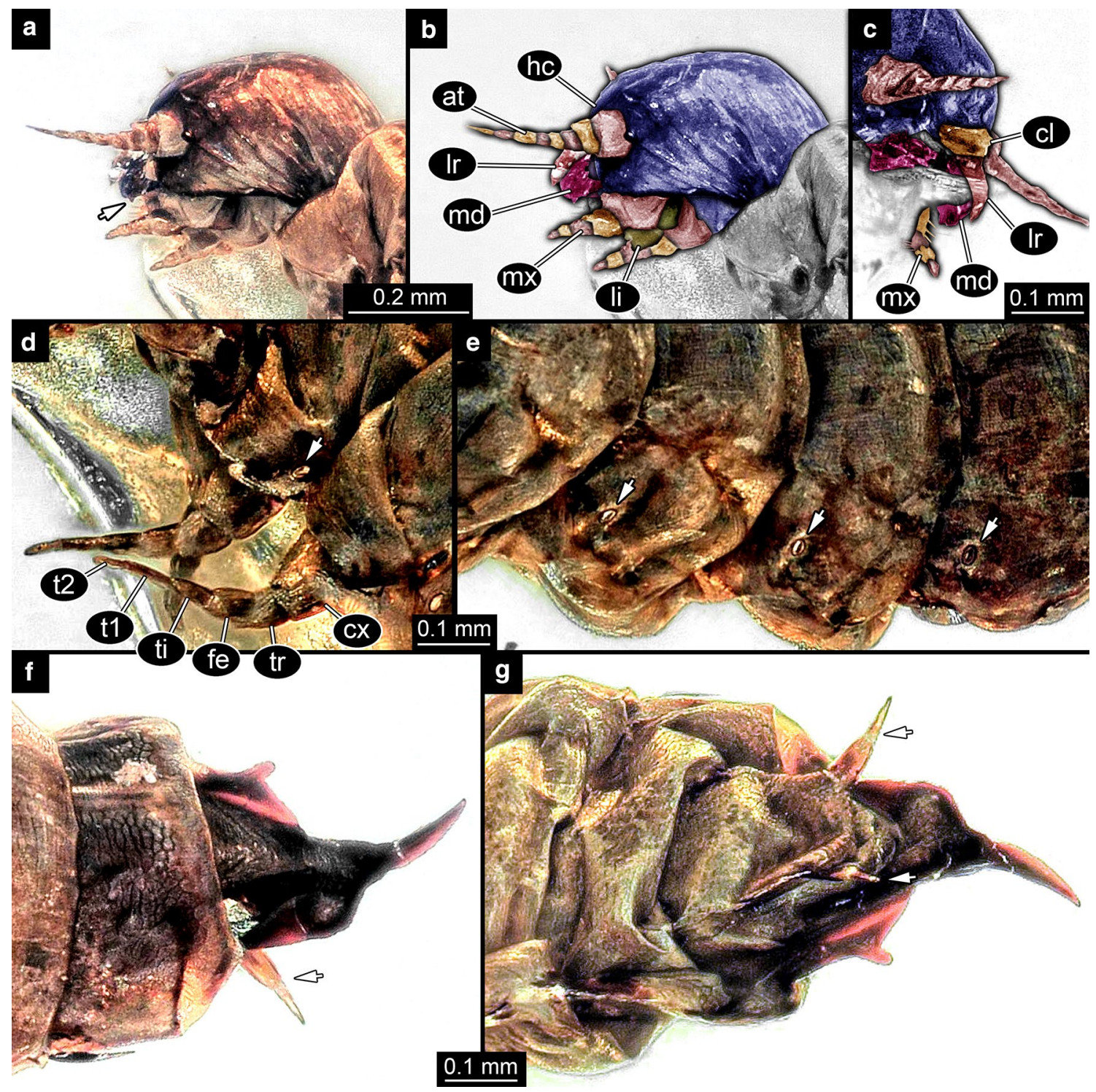

Fig. 3 Fossil specimen BUB 3195, tumbling flower beetle larva: a head in latero-ventral view, a single tooth on mandible discernible (white arrow); $\mathbf{b}$ colour-marked version of $\mathbf{a} ; \mathbf{c}$ colour-marked version of the head region of Fig. 2c; $\mathbf{d}$ close-up of locomotory appendages (legs) in lateral view, tracheal spiracle discernible (white arrow); e close-up of abdomen segments 6-8 in lateral view, tracheal spiracles discernible (white arrows); $\mathbf{f}$ close-up of terminal end with median cuticular elevation and single terminal process in dorsal view, possible urogomphus discernible (white arrow); $\mathbf{g}$ close-up of terminal end with median cuticular elevation and single terminal process in ventral view, possible urogomphi discernible (white arrows). at antenna, $c l$ clypeus, $c x$ coxa, $f e$ femur, $h c$ head capsule, $l i$ labium, $l r$ labrum, $m d$ mandible, $m x$ maxilla, $t 1-2$ tarsus elements $1-2$, $t i$ tibia, $t r$ trochanter
(Fig. 1a). Anal opening constrained by paired lobes ventral on trunk end (Fig. 1a, f). Tracheal spiracles not discernible on abdomen.

\section{Fossil specimen BUB 3195}

Total body length approximately $3.9 \mathrm{~mm}$ (including terminal process) (Fig. 2). Head semicircular from lateral view (Figs. 2a, 3a), $0.4 \mathrm{~mm}$ long. No stemmata discernible.
Antenna (appendage of post-ocular segment 1) with eight elements discernible, $\sim 0.3 \mathrm{~mm}$ long, proximal element largest, further distal elements decreasing in size (Figs. 2b, $3 a-c)$. Mouth parts discernible (Figs. 2b, 3b, c).

Labrum (derivative of ocular segment) $0.1 \mathrm{~mm}$ long, elongated in lateral view, posterior edge connected to prominent clypeus, no setae discernible on anterior edge (Fig. 3c). Mandibles (appendages of post-ocular segment 3) partly accessible (Fig. 3a-c), at least one tooth along gnathal edge 
discernible (Fig. 3a). Maxillae (appendages of post-ocular segment 4) with trapezoid (in ventral view) proximal part, distally with prominent palp $(\sim 0.12 \mathrm{~mm}$ long$)$ with four elements discernible (Fig. 3b). Maxillary palp with three strong setae on proximal element and four fine setae on second element (Fig. 3c), no spines discernible.

Labium (conjoined appendages of post-ocular segment 5) hourglass-shaped in ventral view, with transverse suture dividing it into proximal and distal part (Fig. 3b). Anterior rim of distal part indented medially (Fig. 3b).

Prothorax almost rectangular from lateral view, $0.15 \mathrm{~mm}$ long, appears smallest of all thorax segments (Fig. 2a, b), dorsal body surface subdivided by multiple folds. Mesothorax longer than prothorax, $1.4 \times(\sim 0.21 \mathrm{~mm})$, from lateral view subsimilar to prothorax, dorsal surface with folds. Mesothorax postero-ventrally with oval tracheal spiracle in lateral view (Fig. 3d). Metathorax largest thorax segment, longer than prothorax, $2.1 \times(\sim 0.32 \mathrm{~mm})$.

Legs relatively long ( $\sim 0.4 \mathrm{~mm}$ long) and slender, with six discernible elements (Figs. 2a, b, 3d): coxa, trochanter, femur, tibia, and two elements of tarsus.

Abdomen segments 1-8 subsimilar, length of segments gradually decreasing from anterior to posterior $(0.36-0.20 \mathrm{~mm})$. Antero-ventrally ovate tracheal spiracles discernible on segments 1-8 in lateral view (Fig. 3e). Segment 9 almost rectangular from dorsal view, appears dorsoventrally flatter than abdomen segments $1-8$. Body surface of trunk end strongly sclerotized with single dorsal plate (tergite) and single smaller ventral plate (sternite) (Fig. 3g). Tergite with median sclerotized elevation ending distally with blunt process and single spine-shaped sclerotized terminal process (Fig. 3f, g). Terminal process $\sim 0.2 \mathrm{~mm}$ long with distal end curved upwards. Sternite with pair of postero-lateral processes (possibly urogomphi) in ventral view, possibly each with two elements (Fig. 3f, g).

\section{Discussion}

\section{Lack of record on larvae}

Many representatives of Insecta, especially of Holometabola, such as beetles, moths or flies, spend most of their lifetime as immatures. The lifetime spent as an adult can be very short and sometimes only used for copulation and egg production. Such forms often lack important body parts such as mouth parts or the digestive system, as for example mayflies (Brittain 1982). However, the adult form is often the form that is most often encountered and also considered the taxonomically most important one. In other words, most species descriptions focus on adults, in fact adult males. Larval instars are very often omitted from species descriptions, even though the eco-type they represent and morphologies they show can differ immensely from adults (see discussions in Haug et al. 2020a; Zippel et al. 2022, in review). Often it is forgotten that not only the adults contribute to the large morphological diversity, but the immatures as well (Stehr 1991).

\section{Identity of the fossil larva}

Interpretation of larvae, especially fossil ones, can be challenging due to the mostly adult-centred comparative approaches, similarities among immature forms within different groups, and lack of descriptions of extant larval representatives. In addition, in a fossil a specific characteristic of a certain group can remain inaccessible. This often prevents further determination because the representatives of distantly related groups can, despite great diversity, show remarkable similarity of accessible characteristics (Lawrence 1991b; Haug and Haug 2021).

The new fossil specimen reported here (Figs. 2, 3), for example, shares at a first glance certain characteristics with lepidopteran caterpillars (Kozlov et al. 2002; Vallenduuk and Cuppen 2004; Wagner et al. 2011; Haug and Haug 2021) or extant larvae of beetle groups Chrysomelidae (Lawson 1991; Cox and Windsor 1999; Cabrera et al. 2016; Haug and Haug 2021) or Mordellidae (Hayashi 1980; Odnosum 1992; Voicu and Ivancia 1996; Lisberg and Young 2003; Beutel and Friedrich 2005, Fig. 12b; Odnosum 2007; Odnosum and Litvin 2009; Lawrence and Ślipinśki 2010; Lawrence et al. 2011; Zemoglyadchuk and Buialskaya 2020). Representatives of all three groups can have a similar body shape, a dorsal body surface with folds and a round head with downward orientated cutting-grinding mouth parts. However, most caterpillars are characterised by six stemmata, a median labial gland formed as a spinneret, and additional prolegs (mostly present on abdomen segments 3-6 and 10) sometimes with specialised hooks (Lawrence 1991b; Miller and Hammond 2003; Wagner et al. 2011); the new specimen lacks such structures. Larvae of Chrysomelidae do not have prolegs on the abdomen and some possess prominent maxillary palps (Cabrera et al. 2016), as does the fossil. However, the differences in antenna morphology (Lawson 1991; Lisberg and Young 2003; Lawrence and Ślipinśki 2010) and the absence of a prominent process on the posterior part of the abdomen in larvae of Chrysomelidae, indicate that the fossil is unlikely a representative of Chrysomelidae. In addition, the dorsal surface of larvae of Chrysomelidae and lepidopteran caterpillars sometimes bears numerous setae, protrusions and/or processes and has contrasting colour patterns, which is not the case in the new fossil larva.

The new fossil shares its general appearance (Figs. 1, 2) and a specific single process at the posterior end of the abdomen (Figs. 1a, g, 3f, g) with extant larvae of Mordellidae. 
The process in extant larvae of Mordellidae is either truncate or bifurcate (Lawrence and Ślipinśki 2010; Lawrence et al. 2011) but in general very similar to the process of the here reported new larva.

The differences of the fossil and extant larval representatives of Mordellidae, such as a higher number of elements of antennae (cf. Figs. 1e, 3b), maxillary palps (Fig. 3b, c) and legs (Figs. 2b, 3d), likely represent now extinct specialisation. In modern larvae of Mordellidae, the number of elements of the antennae varies between species, however, the number is mostly between one and three (Franciscolo 1974; Zemoglyadchuk and Buialskaya 2020; Lisberg and Young 2003) and not eight as seen in the new fossil larva (Fig. $3 \mathrm{a}-\mathrm{c}$ ). In this aspect, it should be noted that the Cretaceous ambers have already provided a number of examples of larvae with unusually large antennae (and also other appendages and processes; Haug et al. 2019, 2020b, 2021b). Similar to the antenna, also the maxillary palps with four elements and legs with six elements differ from extant representatives of Mordellidae and are rather prominent. Especially the legs exhibit a similar pattern to the antennae in possessing a rather high number of elements. Extant larvae of Mordellidae have between three or four elements. In some larvae of Mordellistena, legs are even entirely absent. Still, legs with six elements are well known in other larvae of beetles (Lawrence et al. 2011).

Therefore, we interpret the here reported specimen as a tumbling flower beetle-type larva. The specimen has a general appearance and a typical posterior abdomen process of larvae of Mordellidae but still possesses certain specialisations not seen in the modern fauna.

\section{Function of the abdomen process of the new fossil larva}

Larvae of Mordellidae are usually associated with softer organs of plants such as stems in herbaceous plants (Riley 1892; Strong et al. 1984), thorns or galls (Ford and Jackman 1996), or even decaying wood (Zemoglyadchuk and Buialskaya 2020). The larvae bore their way through the plant material with their mouth parts, often leaving a tunnel behind them (Chiappini and Nicoli Aldini 2011). However, some larvae are capable of boring into compact and woody substrates as well (Lawrence 1991a). Lisberg and Young (2003) reported that larvae of Tomoxia lineella were found $20 \mathrm{~mm}$ under the bark of healthy large-toothed aspen trees, demonstrating their capabilities of also boring into wood (although aspen wood is generally somewhat softer).

The wood-boring larvae in general are often characterised by specialisations for their lifestyle such as strong chewing mandibles, body structures for anchoring, and tracheal spiracles possessing filtering mechanisms (Cymorek 1968; Chiappini and Nicoli Aldini 2011). There is a variety of structures that help different wood-boring larvae with anchoring while they chew through the plant material (Grandi 1951; Ross and Pothecary 1970; Lawrence 1991b; Young 2001; Grebennikov 2004; Chiappini and Nicoli Aldini 2011; Lawrence et al. 2011; Gimmel and Leschen 2014; Yavorskaya et al. 2015; Chang et al. 2016; Zemoglyadchuk and Buialskaya 2020; Zippel et al. in review). In particular, the processes that are curved as hooks seem to provide a strong grip on the material they attach to, as demonstrated in the case of hooked setae of the lepidopteran pupa of the species Greta oto (Ingram and Parker 2006). Another example of upcurved processes is seen in some of the larvae of Tenebrionidae (in particular Glyptotus cribratus and Cibdelis blaschkei; Steiner 2014). However, here the upcurved urogomphi are not used to anchor the larva (at least not only) but to perform pinching movements against the cuticular elevations on the tergite of the prior abdomen segment. In this way, these structures on the abdomen are used for defence within a wood tunnel, enabling the larva to defend itself either anteriorly with mandibles or posteriorly with the pinching process (Steiner 2014).

The newly described larval specimen has a terminal process and a median elevation of cuticle anteriorly. However, the elevation here is on the same sclerite and relatively close to the process (Fig. 3f, g); it also lacks any type of articulation. Therefore, the process could presumably not bend and perform the pinching movements as in Glyptotus and Cibdelis (Steiner 2014). More likely, this larva used the upcurved process and the median elevation for anchoring while burrowing through wood and/or fungi material. In addition to the single process, the fossil larva bears paired ventral processes on abdomen segment 9; as this specimen is a beetle larva, these might represent urogomphi. However, articulated paired urogomphi with two elements that occur within the extant larvae of Aspidytidae, Histeridae, Hydrophilidae (specifically in larvae of Helophorus) and several groups of Staphylinoidea do not resemble the urogomphi of the new fossil larva. According to Lawrence et al. (2011), urogomphi probably evolved in groups where larvae live in enclosed spaces or dense substrates, and they allow larvae moving backwards through the tunnel. With this background, we cannot exclude that the structures of the larva are more unusual types of urogomphi.

\section{Possible ecology of tumbling flower beetle-type larva}

The fossil specimen is preserved in 99 million-year-old Myanmar amber from Cretaceous. At that time the flowering plants were rather common (Bao et al. 2019b) with a wide spectrum of well-differentiated lineages (Friis et al. 2006). Still the terrestrial vegetation was still dominated by plants of various other ingroups of Spermatophytina 
(Coniferopsida, Cycadopsida, Ginkgoopsida, and Bennettitales) and also seed ferns (including Corystospermales and Caytoniales) (Peris et al. 2020). The fossil record supports the idea that beetles were among the first pollinators of seed plants in general, also including Magnoliopsida (Peris et al. 2020). Some beetles of the group Kateretidae specialised on pollination of early seed plants (Cycadopsida, Ginkgoopsida, and Bennettitales) and flowering plants (Nymphaeaceae). They possibly represented an early example of the transition from pollinating early land plants to pollinating flowering plants (Peris et al. 2020). Mordellidae seems to be one of the groups with adults that successfully adapted to flowering plant pollination and co-evolved further with early lineages of Magnoliopsida (Bao et al. 2019b). Such beetle-plant interactions at early stage of flowering plant diversification did not dominate the Kachin amber forests (Bao et al. 2019d). Some Mesozoic adults of Mordellidae missed a long and prolongated pointy trunk end that is a characteristic of extant and Eocene adults of the group. Together with other characteristics, this implies that there was probably a change in locomotion leading to different, flower-oriented, feeding behaviour (Bao et al. 2018). Based on fossil specimens included in Cretaceous amber of Spain, Peris and Rust (2020, tab. 1) concluded that the adult tumbling flower beetles in the Cretaceous were mostly associated with fungi, decaying wood and flowers. This is also the case for extant tumbling flower beetles, both immature and adult. Therefore, it is possible that the new larva fed on soft parenchymal internal plant tissues, like many other beetles (Labandeira 2010) or decaying wood infested with fungi. We can presume that it used its specific processes for anchoring while feeding. These structures, in addition to the presence of urogomphi, support the idea of similar lifestyle to modern larvae of Mordellidae, within plant tissues. It seems that in fact many beetles in the Cretaceous, and especially their larvae, were xylophagous (Peris et al. 2016; Haug and Haug 2019; Haug et al. 2021c; Zippel et al. 2022, in review) and contributed to wood decomposition and carbon cycling (Tate et al. 1993; Grove 2002; Zippel et al. 2022, in review). This should of course not be entirely surprising, as it seems that also among extant beetles saproxilicity has been proposed to represent the most common way of life (Gimmel and Ferro 2018). Still, fossil beetle larvae with this lifestyle are still rather rare (Peris and Rust 2020). The new larva reported here is another possible addition to the list of such larvae in the Cretaceous.

\section{Conclusions}

1. Until now, there was no fossil record of larvae of Mordellidae. We are reporting the presumably first fossil larva of Mordellidae; it is preserved in Cretaceous Kachin amber from Myanmar. The fossil larva has similarities in general appearance and in the terminal abdomen process with extant larvae of Mordellidae.

2. The new fossil larva possesses certain specialisations not seen in the modern fauna. The fossil larva has more prominent antennae, maxillary palps and legs (all with more elements than in modern representatives of Mordellidae).

3. The fossil larva possibly lived in forests within wood where it contributed to wood decomposition.

Acknowledgements We thank Martin Husemann and Thure Dalsgaard, Centrum für Naturkunde (CeNak), Leibniz-Institut zur Analyse des Biodiversitätswandels (LIB), Hamburg, for providing access to the collections. Our thanks go to the students from LMU Munich assisting with imaging during the excursion to Hamburg in 2019, and to Lehre@ LMU and to the Faculty of Biology of the LMU for financial support of the excursion. We also want to thank the anonymous reviewer for insightful suggestions that helped improve the quality of this manuscript. The study is supported by the German Research Foundation (DFG Ha 6300/6-1) and the Volkswagen Foundation with a Lichtenberg professorship to JTH. J. Matthias Starck, Munich, is thanked for long-time support. We thank all people providing low-cost, open-access or open-source software. This is LEON publication \#32.

Author contributions Conceptualization: AZ, CH, and JTH; methodology: $\mathrm{CH}, \mathrm{PM}, \mathrm{JTH}$, and AZ; investigation: $\mathrm{AZ}, \mathrm{JTH}, \mathrm{CH}$, and PM; writing - original draft preparation: $\mathrm{AZ}, \mathrm{CH}$, and JTH; writingreview and editing: AZ, CH, PM, and JTH; funding acquisition: JTH; resources: PM and JTH.

Funding Open Access funding enabled and organized by Projekt DEAL.

Availability of data and material All data are provided in the text and the figures.

Code availability Not applicable.

\section{Declarations}

Conflict of interest The authors declare that they have no conflicts of interest and no competing interests.

Open Access This article is licensed under a Creative Commons Attribution 4.0 International License, which permits use, sharing, adaptation, distribution and reproduction in any medium or format, as long as you give appropriate credit to the original author(s) and the source, provide a link to the Creative Commons licence, and indicate if changes were made. The images or other third party material in this article are included in the article's Creative Commons licence, unless indicated otherwise in a credit line to the material. If material is not included in the article's Creative Commons licence and your intended use is not 
permitted by statutory regulation or exceeds the permitted use, you will need to obtain permission directly from the copyright holder. To view a copy of this licence, visit http://creativecommons.org/licenses/by/4.0/.

\section{References}

Bao, T., K.S. Walczyńska, S. Moody, B. Wang, and J. Rust. 2018. New family Aptomouridae fam. Nov. (Coleoptera: Tenebrionoidea) from lower Cenomanian amber of Myanmar. Cretaceous Research 91: 14-19.

Bao, T., K.S. Walczyńska, B. Bojarski, E. Jarembowski, B. Wang, and J. Rust. 2019a. A new species of tumbling flower beetle (Coleoptera: Mordellidae) from Baltic amber. PalZ 93: 31-36.

Bao, T., B. Wang, J. Li, and D. Dilcher. 2019b. Pollination of Cretaceous flowers. Proceedings of the National Academy of Sciences 116 (49): 24707-24711.

Bao, T., X.S. Zhang, K.S. Walczyska, B. Wang, and J. Rust. 2019c. Earliest mordellid-like beetles from the Jurassic of Kazakhstan and China (Coleoptera: Tenebrionoidea). Proceedings of the Geologists' Association 130: 247-256. https://doi.org/10.1016/j. pgeola.2019.02.002.

Bao, T., K.S. Walczyńska, S. Moody, B. Wang, and J. Rust. 2019d. The first true Mordellidae (Coleoptera: Tenebrionoidea) from lower Cenomanian amber of Myanmar. Cretaceous Research 93: 60-65. https://doi.org/10.1016/j.cretres.2018.09.008.

Beutel, R.G., and F. Friedrich. 2005. Comparative study of larvae of Tenebrionoidea (Coleoptera: Cucujiformia). European Journal of Entomology 102: 241-264.

Brittain, J.E. 1982. Biology of mayflies. Annual Review of Entomology 27 (1): 119-147. https://doi.org/10.1146/annurev.en.27.010182. 001003.

Cabrera, N., A. Sosa, M. Telesnicki, and M. Julien. 2016. Morphology of juvenile stages of Kuschelina bergi (Harold) with biological information (Coleoptera, Chrysomelidae, Alticini). ZooKeys 561: 51-61. https://doi.org/10.3897/zookeys.561.5950.

Chang, H.L., J. Muona, H.Y. Pu, L. Xu, C. Wang, M. Teräväinen, D. Ren, Q. Yang, X.L. Zhang, and S.H. Jia. 2016. Chinese Cretaceous larva exposes a southern Californian living fossil (Insecta, Coleoptera, Eucnemidae. Cladistics 32: 211-214. https://doi.org/ 10.1111/cla.12124.

Chiappini, E., and R. Nicoli Aldini. 2011. Morphological and physiological adaptations of wood-boring beetle larvae in timber. Journal of Entomological and Acarological Research 43 (2): 47-59.

Cox, M.L., and D.M. Windsor. 1999. The first instar larva of Aulacoscelis appendiculata $\mathrm{n}$. sp. (Coleoptera: Chrysomelidae: Aulacoscelinae) and its value in the placement of the Aulacoscelinae. Journal of Natural History 33: 1049-1087. https://doi.org/10. 1080/002229399300083.

Cruickshank, R.D., and K. Ko. 2003. Geology of an amber locality in the Hukawng Valley, northern Myanmar. Journal of Asian Earth Sciences 21 (5): 441-455. https://doi.org/10.1016/S13679120(02)00044-5.

Cymorek, S. 1968. Adaptations in wood-boring insects: examples of morphological, anatomical, physiological and behavioural features. In Record of the 18th Annual Convention of the British Wood Preservation Association, 1968, pp. 161-180.

Ford, E.J., and J.A. Jackman. 1996. New larval host plant association of tumbling flower beetle (Coleoptera: Mordellidae) in North America. The Coleopterists Bulletin 50 (4): 361-368.

Franciscolo, M.E. 1974. New and little-known Mordellistena Costa from Pakistan and India (Coleoptera: Mordellidae). Oriental Insects 8 (1): 71-84. https://doi.org/10.1080/00305316.1974. 10434445 .
Friis, E.M., K.R. Pedersen, and P.R. Crane. 2006. Cretaceous angiosperm flowers: Innovation and evolution in plant reproduction. Palaeogeography, Palaeoclimatology, Palaeoecology 232 (2-4): 251-293.

Gimmel M.L., and M.L., Ferro. 2018. General overview of saproxylic Coleoptera. In Saproxylic insects: diversity, ecology and conservation, ed. M.D. Ulyshen, pp. 51-128. Heidelberg: Springer. https://doi.org/10.1007/978-3-319-75937-1_2

Gimmel, M.L., and R.A.B. Leschen. 2014. A new species of mycophagous Rentonium (Coleoptera: Cleroidea: Trogossitidae) based on larvae and adults, and a catalogue of Rentoniinae. Journal of Natural History 48 (15-16): 863-880. https://doi.org/10.1080/ 00222933.2013 .839846$.

Grandi, G. 1951. Introduzione allo studio dell'entomologia: Organizzazione, sviluppo, vita. Apterigoti ed Esopterigoti, Vol. 2, 1-1332. (Vol. 2). Bologna: Edagricole. p. 1332.

Grebennikov, V.V. 2004. Review of larval morphology of the suborder Archeostemata (Insecta: Coleoptera), including first-instar chaetotaxy. European Journal of Entomology 101: 273-292.

Grove, S.J. 2002. Saproxylic insect ecology and the sustainable management of forests. Annual Review of Ecology, Evolution, and Systematics 33: 1-23. https://doi.org/10.1146/annurev.ecolsys.33. 010802.150507.

Haug, J.T., and C. Haug. 2019. Beetle larvae with unusually large terminal ends and a fossil that beats them all (Scraptiidae, Coleoptera). PeerJ 7: e7871. https://doi.org/10.7717/peerj.7871.

Haug, J.T., and C. Haug. 2021. A 100 million-year-old armoured caterpillar supports the early diversification of moths and butterflies. Gondwana Research 93: 101-105. https://doi.org/10. 1016/j.gr.2021.01.009.

Haug, C., G. Mayer, V. Kutschera, D. Waloszek, A. Maas, and J.T. Haug. 2011. Imaging and documenting gammarideans. International Journal of Zoology 2011: 380829. https://doi.org/10. 1155/2011/380829.

Haug, C., K.R. Shannon, T. Nyborg, and F.J. Vega. 2013a. Isolated mantis shrimp dactyli from the Pliocene of North Carolina and their bearing on the history of Stomatopoda. Bolétin De La Sociedad Geológica Mexicana 65: 273-284. https://doi.org/10. 18268/BSGM2013v65n2a9.

Haug, J.T., C.H.G. Müller, and A. Sombke. 2013b. A centipede nymph in Baltic amber and a new approach to document amber fossils. Organisms Diversity and Evolution 13: 425-432. https:// doi.org/10.1007/s13127-013-0129-3.

Haug, J.T., P. Müller, and C. Haug. 2018. The ride of the parasite: A 100-million-year old mantis lacewing larva captured while mounting its spider host. Zoological Letters 4: 31. https://doi. org/10.1186/s40851-018-0116-9.

Haug, J.T., P. Müller, and C. Haug. 2019. A 100-million-year old slim insectan predator with massive venom-injecting stylets-a new type of neuropteran larva from Burmese amber. Bulletin of Geosciences 94 (4): 431-440. https://doi.org/10.3140/bull. geosci.1753.

Haug, J.T., P. Müller, and C. Haug. 2020a. A 100 million-year-old snake-fly larva with an unusually large antenna. Bulletin of Geosciences 95 (2): 167-177. https://doi.org/10.3140/bull.geosci. 1757.

Haug, J.T., M. Schädel, V. Baranov, and C. Haug. 2020b. An unusual100-million-year old holometabolan larva with a piercing mouth cone. PeerJ 8: e8661. https://doi.org/10.7717/peerj.8661.

Haug, C., G.T. Haug, A. Zippel, S. van der Waal, and J.T. Haug. 2021a. The earliest record of fossil solid-wood-borer larvaeimmature beeltes in 99 million-year-old Myanmar amber. Palaeoentomology 004 (4): 390-404. https://doi.org/10.11646/ palaeoentomology.4.4.14.

Haug, J.T., V. Baranov, P. Müller, and C. Haug. 2021b. New extreme morphologies as exemplified by 100 million-year-old lacewing 
larvae. Scientific Reports 11: 20432. https://doi.org/10.1038/ s41598-021-99480-w.

Haug, J.T., A. Zippel, G.T. Haug, C. Hoffeins, H.-W. Hoffeins, J.U. Hammel, V. Baranov, and C. Haug. 2021c. Texas beetle larvae (Brachypsectridae)-The last 100 million years reviewed. Palaeodiversity 14 (1): 161-183.https://doi.org/10.18476/pale. v14.a8.

Hayashi, N. 1980. Illustrations for identification of larvae of the Cucujoidea (Coleoptera) found living in dead trees in Japan. Memoirs of the Education Institute for Private Schools in Japan 72: 95-147.

Ingram, A.L., and A.R. Parker. 2006. Structure, mechanism and mechanical properties of pupal attachment in Greta oto (Lepidoptera: Nymphalidae: Ithomiinae). Entomological Science 9: 109-120. https://doi.org/10.1111/j.1479-8298.2006.00158.x.

Jackman, J.A., and W. Lu. 2002. Mordellidae Latreille 1802. In American Beetles. Polyphaga: Scarabaeoidea through Curculionoidea, ed. R.H. Arnett, M.C. Thomas, P.E. Skelley, and J.F. Howard, 423-430. West Palm Beach: CRL Press LLC.

Kozlov, M.V., V.D. Ivanov, and A.P. Rasnitsyin. 2002. 2.2.1.3.4.3. Order Lepidoptera Linne, 1758. The Butterflies and Moths (=Papilionida Laicharting, 1781). In History of insects, ed. A.P. Rasnitsyn and D.L.J. Quicke, 220-227. Dodrecht-BostonLondon: Kluver Kluwer Academic Publishers.

Labandeira, C.C. 2010. The pollination of mid Mesozoic seed plants and the early history of long-proboscid insects. Annals of the Missouri Botanical Garden 97 (4): 469-513.

Lawrence, J.F. 1991a. Mordellidae (Tenebrionoidea). In Immature insects, vol. 2, ed. F.W. Stehr, 508-509. Dubuque: Kendall-Hunt Publishing Co.

Lawrence, J.F. 1991b. Order Coleoptera. In Immature insects, vol. 2, ed. F.W. Stehr, 144-237. Dubuque: Kendall-Hunt Publishing Co.

Lawrence, J.F., and S.A. Ślipinśki. 2010. Mordellidae Latreille, 1802. In Handbook of Zoology, Coleoptera, Beetles, morphology and systematics (Elateroidea, Bostrichiformia, Cucujiformia Partim), vol. 2, ed. R.A.B. Leschen, R.G. Beutel, and J.F. Lawrence, 533537. Berlin and New York: Walter de Gruyter.

Lawrence, J.F., A. Ślipinśki, A.E. Seago, M.K. Thayer, A.F. Newton, and A.E. Marvaldi. 2011. Phylogeny of the Coleoptera based on morphological characters of adults and larvae. Annals of Zoology 61: 1-217. https://doi.org/10.3161/000345411X576725.

Lawson, F.A. 1991. Chrysomelidae (Chrysomeloidea) (= Cassididae, Cryptocephalidae, Megalopodidae, Sagridae, etc.). In Immature insects, vol. 2, ed. F.W. Stehr, 568-585. Dubuque: Kendall-Hunt Publishing Co.

Lisberg, A., and D.K. Young. 2003. Descriptions of larva and pupa of Tomoxia lineella LeConte with notes on larval habitat (Coleoptera: Mordellidae). The Coleopterists Bulletin 57 (3): 339-344. https://doi.org/10.1649/571.

Liu, X., G. Shi, F. Xia, X. Lu, B. Wang, and M.S. Engel. 2018. Liverwort mimesis in a Cretaceous lacewing larva. Current Biology 28 (9): 1475-1481. https://doi.org/10.1016/j.cub.2018.03.060.

McKenna, D.D., and B. Farrell. 2009. Beetles (Coleoptera). In The time-tree of life, ed. S.B. Hedges and K. Kumar, 278-289. Oxford: Oxford University Press.

Miller, J.C., and P.C. Hammond. 2003. Lepidoptera of the Pacific Northwest: Caterpillars and adults, 1-324, 324. Washington, D.C.: US Department of Agriculture, Forest Health Technology Enterprise Team, Forest Service.

Odnosum, V.K. 1992. The larvae of mordellid beetles (Coleoptera, Mordellidae) of the USSR. Entomological Review 71: 118-132.

Odnosum, V.K. 2007. Description of larva of tumbling flower beetle Mordellistena kraatzi (Coleoptera: Mordellidae). Vestnik Zoologii 41 (1): 85-86. In original (Описание личинки жука-горбатки Mordellistena kraatzi (Coleoptera, Mordellidae).
Odnosum, V.K., and O. Litvin. 2009. Descripton of Mordellistena parvuliformis larva (Coleoptera, Mordellidae). Vestnik Zoologii 43 (6): 18-20. https://doi.org/10.2478/v10058-009-0023-9.

Peris, D., and J. Rust. 2020. Cretaceous beetles (Insecta: Coleoptera) in amber: The palaeoecology of this most diverse group of insects. Zoological Journal of the Linnean Society 189: 1085-1104. https://doi.org/10.1093/zoolinnean/zlz118.

Peris, D., and E. Ruzzier. 2013. A new tribe, new genus, and new species of Mordellidae (Coleoptera: Tenebrionoidea) from the Early Cretaceous amber of Spain. Cretaceous Research 45: 1-6. https:// doi.org/10.1016/j.cretres.2013.07.002v

Peris, D., E. Ruzzier, V. Perrichot, and X. Delclòs. 2016. Evolutionary and palaeobiological implications of Coleoptera (Insecta) from Tethyan-influenced Cretaceous ambers. Geoscience Frontiers 7: 695-706. https://doi.org/10.1016/j.gsf.2015.12.007.

Peris, D., C.C. Labandeira, E. Barron, X. Delclos, J. Rust, and B. Wang. 2020. Generalist pollen-feeding beetles during the midCretaceous. iScience 23 (3): 100913. https://doi.org/10.1016/j. isci.2020.100913.

Riley, C.V. 1892. Coleopterous larvae with so-called dorsal prolegs. Proceedings of the Entomological Society of Washington 2: 319-325.

Ross, D.A., and D.D. Pothecary. 1970. Notes on adults, eggs, and first-instar larvae of Priacma serrata (Coleoptera:Cupedidae). The Canadian Entomologist 102 (3): 346-348. https://doi.org/ 10.4039/Ent102346-3.

Ščegoleva-Barovskaya, T.I. 1929. Der erste Vertreter der Familie Mordellidae (Coleoptera) aus der Juraformation Turkestans. Comptes Rendus De L'academie Des Sciences De l'URSS 8: 27-29.

Shi, G., D.A. Grimaldi, G.E. Harlow, J. Wang, J. Wang, M. Yang, W. Lei, Q. Li, and X. Li. 2012. Age constraint on Burmese amber based on U-Pb dating of zircons. Cretaceous Research 37: 155163. https://doi.org/10.1016/j.cretres.2012.03.014.

Stehr, F.W. 1991. Introduction. In Immature insects, vol. 2, ed. F.W. Stehr, XV-XVI. Dubuque: Kendall-Hunt Publishing Co.

Steiner, W.E., Jr. 2014. Larvae and pupae of two North American darkling beetles (Coleoptera, Tenebrionidae, Stenochiinae), Glyptotus cribratus LeConte and Cibdelis blaschkei Mannerheim, with notes on ecological and behavioural similarities. ZooKeys 415: 311. https://doi.org/10.3897/zookeys.415.6891.

Strong, D.R., J.H. Lawton, and R. Southwood. 1984. Insects on plants, community patterns and mechanisms, 1-313. Cambridge: Harvard University Press.

Tate, K.R., D.J. Ross, B.J. O’Brien, and F.M. Kelliher. 1993. Carbon storage and turnover, and respiratory activity, in the litter and soil of an old-growth southern beech (Nothofagus) forest. Soil Biology and Biochemistry 25: 1601-1612. https://doi.org/10.1016/00380717(93)90016-5.

Vallenduuk, H.J., and H.M.J. Cuppen. 2004. The aquatic living caterpillars (Lepidoptera: Pyraloidea: Crambidae) of Central Europe. A key to the larvae and autecology. Lauterbornia 49: 1-17.

Voicu, M.C., and V. Ivancia. 1996. The beetle Mordellistena parvula Gyll. (Coleoptera, Mordellidae), a new sunflower pest in Romania. Romanian Agricultural Research 5-6: 83-85.

Wagner, D.L., D.F. Schweitzer, J.B. Sullivan, and R.C. Reardon. 2011. Owlet caterpillars of eastern North America (Lepidoptera: Noctuidae), 1-576. Princeton: Princeton University Press.

Wang, W.L. 1993. On Liaoximordellidae fam. nov. (Coleoptera, Insecta) from the Jurassic of western Liaoning Province, China. Acta Geologica Sinica 67: 86-94.

Yavorskaya, M.I., K. Kojima, R. Machida, and R.G. Beutel. 2015. Morphology of the first instar larva of Tenomerga mucida (Chevrolat, 1829)(Coleoptera: Archostemata: Cupedidae). Arthropod Systematics and Phylogeny 73 (2): 239-258. 
Young, D.K. 2001. 1. Cupedidae Laporte, 1836. In American beetles, vol. 1, ed. R.H. Arnett Jr. and M.C. Thomas, 19-21. Boca Raton: CRC Press.

Yu, T., R. Kelly, L. Mu, A. Ross, J. Kennedy, P. Broly, F. Xia, H. Zhang, B. Wang, and D. Dilcher D. 2019. An ammonite trapped in Burmese amber. Proceedings of the National Academy of Sciences 116 (23): 11345-11350. https://doi.org/10.1073/pnas.18212 92116.

Zemoglyadchuk, A.V., and N.P. Buialskaya. 2016. Research findings in morphology of mordellid beetles larvae (Coleoptera, Mordellidae). BarSU Herald 4: 27-34.
Zemoglyadchuk, A.V., and N.P. Buialskaya. 2020. Description of the larvae of three species of the genus Mordellistena (Coleoptera: Mordellidae) with notes on their ecology. Zootaxa 4743 (3): $371-$ 381. https://doi.org/10.11646/zootaxa.4743.3.4.

Zippel, A., C. Haug, C. Hoffeins, H.-W. Hoffeins, and J.T. Haug. 2022. Expanding the record of larvae of false flower beetles with prominent terminal ends. Rivista Italiana di Paleontologia e Stratigrafia 128 (1): 81-104.

Zippel, A., C. Haug, P. Müller, and J.T. Haug. in review. The first fossil false click beetle larva preserved in amber. PalZ. Paläontologische Zeitschrift. 